\author{
Alina Walenia \\ University of Rzeszow \\ Faculty of Economics \\ Department of Economic Policy \\ e-mail: alinawalenia@poczta.onet.pl
}

\title{
Ethical Standards in the Process of Counteracting Financial Abuse with Regard to EU Budget Funds. The Case of Poland
}

\begin{abstract}
In accordance with the binding regulations of the EU law, each institution participating in the EU funds management process has in place relevant procedures preventing fraud and corruption and discouraging people from taking such actions. Managing institutions that work in cooperation with organisations which participate in the implementation of EU funds ensures the operation of an effective fraud risk management system and the implementation of effective anti-fraud means which are designed to protect the financial interests of the European Union. The ethical norms and principles implemented in institutions which coordinate the process of EU funds management are of great importance for the process of reducing fraud related to EU funds. It was confirmed with the results of research carried out that clearly defined standards of employee conduct and determining procedures in the management and control system were the most important factors mitigating the irregularities. A special place was reserved for complying with the norms of ethical conduct and honesty by the employees of institutions managing the EU funds and development of a Code of Ethics which describes the conduct of the employees of institutions participating in the EU funds management process. The anti-fraud procedures presented herein stem from EU law and are applicable in Poland.
\end{abstract}

Keywords: financial fraud, EU funds, ethical norms

JEL Classification D73, H83 


\section{Preliminary remarks}

The financial fraud that may occur in connection with the implementation of operational programmes co-financed by EU funds is extremely dangerous. They infringe the principle of fair competition, and they negatively affect the image of the institutions participating in the process and of people managing them. The most frequent financial fraud related to the implementation of operational programmes co-financed by the EU include tender conspiracy, conflict of interest, corruption and the falsification of documents.

Financial fraud reduces the confidence of citizens in the authorities and institutions participating in the EU funds management process. By breaking generally accepted legal and ethical norms, they contribute to the EU's financial damage, endangering public property and hindering the economic development of the areas in which they occur.

The purpose of this paper is to assess the importance of ethical norms in the process of reducing financial fraud associated with the implementation of EU funds. Based on existing EU and national legislation and the principles of the ethical behaviour of the employees of the institutions involved in the management of operational programmes, methods for reducing the financial fraud are presented. The main research thesis was formulated as follows: the principles and ethical norms implemented by institutions coordinating the management of EU funds play an important role in the process of reducing financial fraud involving EU funds. In spite of the detailed regulation of this issue in EU and national laws, the extent of the financial fraud is considerable, and therefore a particular role has been attributed to the ethical principles and norms that should be respected at various stages of EU project management.

\section{Definition and characterisation o financial fraud involving EU funds}

According to Article 59 paragraph 2 of Financial Regulation No. 966/2012 1 applicable to the EU budget, it is the task of the managing authorities to adopt and implement all the necessary measures to protect the EU's financial interests, in particular through the prevention of irregularities and financial fraud, their detection and correction. According to Article 125 paragraph 4 c) of EU Regulation No. 1303/2013 of the European Parliament and of the Council², managing authorities implement effective and proportionate anti-fraud measures, taking into

\footnotetext{
${ }^{1}$ Regulation of the European Parliament and of the Council (EU, Euratom) No 966/2012 of 25 October 2012, on the financial rules applicable to the general budget of the Union and repealing Council Regulation (EU, Euratom) No. 1605/2002 (OJ No. UE L 298/4 of 26.10.2016).

${ }^{2}$ Regulation (EU) No 1303/2013 of the European Parliament and of the Council of 17 December 2013 laying down common provisions for the European Regional Development Fund, the European Social Fund, the Cohesion Fund, the European Agricultural Fund for Rural Development and the European Maritime and Fisheries Fund and laying down general provisions for the European Regional Development Fund, the European Social Fund, the Cohesion Fund and the European Maritime and Fisheries Fund and repealing Council Regulation (EC) No. 1083/2006.
} 
account the identified kinds of risks. Those tasks are based on Article 72 b) of Regulation No. 1303/2013, which states that management and control systems are intended to prevent, detect and correct irregularities, including financial fraud, and to recover unduly paid amounts together with interest on their repayment after the deadline. Addressing the problems of financial fraud, its causes and consequences is an important and difficult challenge, as financial fraud is planned so as to be undetected..$^{3}$ Implementing the established methods of the financial fraud management and control mechanisms is a tool to ensure that attempts to defraud the EU budget funds connected with the implementation of operational programmes will not be possible and their occurrence will be promptly reported to the appropriate authorities. ${ }^{4}$

Fraud is unethical, often illegal behaviour, aimed at achieving personal, usually financial, benefits. There are many definitions of this term that more or less exhaustively describe this phenomenon. The most commonly used definition is the one developed by the Association of Certified Fraud Examiners of the Institute of Internal Auditors and of the American Institute of Chartered Accountants. ${ }^{5}$ According to that definition, economic fraud is any intentional act or negligence that results in the gaining or losing of any benefit by the perpetrator by way of misleading. The convention on the protection of the European Communities' financial interests, drawn up on the basis of Article K.3 of the Treaty on the European Union ${ }^{6}$, defines financial fraud as a deliberate act or omission:

(1) in relation to expenditure consisting of:

- the use or presentation of untrue, incorrect or incomplete statements or documents intended to mislead or unlawfully retain funds from the general budget of the EU,

- the non-disclosure of information in breach of a specific obligation, for the same purpose,

- the improper use of such funds for purposes other than those originally assumed,

(2) in relation to revenue, concerning:

- the use or presentation of false, inaccurate or incomplete statements or documents intended to reduce the EU general budget unduly,

- the non-disclosure of information in breach of a specific obligation, for the same purpose,

- the improper use of legitimately obtained benefits for the same purpose.

\footnotetext{
${ }^{3}$ J. Łacny, Ochrona interesów finansowych Unii Europejskiej w dziedzinie polityki spójności, Wolters Kluwer, Warsaw 2010.

${ }^{4}$ K. Dziadek, Kontrola jako narzędzie wykrywania nieprawidłowości w wykorzystaniu funduszy unijnych, "Zeszyty Naukowe Uniwersytetu Szczecińskiego" 2011, No. 42, pp. 111-119.

${ }^{5}$ ACFE Polska Association of Certified Fraud Examiners is a non-profit organization of professionals working on the prevention and detection of business fraud. ACFE Polska is No. 114 Chapter of ACFE, recognized by ACFE in the United States. Members of the Association are subject to the Code of Ethics. The purpose of the organization is to educate the members in order to update their skills in the research and provision of counselling services in the field of economic crime and fraud prevention and detection. ACFE Polska was established in July 2003 and immediately began its efforts to be recognized as an ACFE Chapter in the United States. In September it was officially recognized as Poland Chapter No. 114, and in October 2003 it was registered in the National Court Register

${ }^{6}$ OJ 2004.90.864/30 - Treaty of the European Union - consolidated text incorporating the amendment introduced by the Treaty of Lisbon.
} 
According to Article 2 paragraph 36 of Regulation No 1303/2013, an irregularity is any infringement of EU or national law concerning the application of EU law resulting from the act or the omission of an economic operator involved in the implementation of the EFSI, i.e., funds providing support under the cohesion policy. This includes the European Regional Development Fund, the European Social Fund, the Cohesion Fund and the European Agricultural Fund for Rural Development and Maritime and Fisheries Funds, i.e., the funds financed under the shared management of the European Maritime and Fisheries Fund, which has or may have a detrimental effect on the Union budget by charging that budget with unreasonable expense.

The difference between financial fraud and an irregularity lies in the intention. The suspicion of financial fraud is an irregularity leading to the initiation of administrative and/or judicial proceedings at national level in order to determine the intended action, in particular the financial fraud under Article 1 paragraph A of the Convention on the protection of the European Communities' financial interests, pursuant to Article K.3 of the Treaty on the European Union. In order to standardise the approach of institutions involved in the implementation of operational programmes for the period 2014-2020, for the process of preventing and combating financial fraud, the most prevalent financial frauds which have the greatest impact on the process of spending EU funds in the implementation of operational programmes were characterised. Those different types of financial fraud do not constitute an exhaustive list. New practices and methods of crime that meet the definitions of financial fraud may be identified in the implementation of operational programmes. The most serious financial fraud is tender conspiracy?

\section{Responsibilities of the Member States to set up a management and control system for $E U$ funds}

In connection with the fulfilment of obligations under Article 125 paragraph $4 \mathrm{c}$ ) of Regulation No. 1303/2013, the managing authority, in cooperation with the institutions participating in the implementation of EU funds, shall ensure the operation of a reasonable financial fraud management system and shall introduce proportionate and effective means of combating them to protect the EU's financial interests. Institutions participating in the implementation of operational programmes in 2014-2020 are guided by their policy of absolute non-tolerance of financial fraud, both in terms of their organisational structures and the behaviour of the Applicants and Beneficiaries. According to the EC guidelines ${ }^{8}$, institutions implementing the operational programmes should apply the following general principles in the financial fraud risk management process:

\footnotetext{
${ }^{7}$ Office of Competition and Consumer Protection, Activity reports, "Tender Conspiracy" 2016; G. Borowik, Zwalczanie zmów cenowych jako zagrożenia ekonomicznych interesów RP-próba oceny skuteczności unormowań prawnych, „Przegląd Bezpieczeństwa Wewnętrznego” 2013, No. 9(5), pp. 167-193.

${ }^{8}$ Guideline of the European Commission's Directorate-General "Assessment of the risks of financial fraud and effective and proportionate anti-fraud measures”, EGESIF_14-0021-00 16/06/2015, June 2014.
} 
(1) make an appropriate assessment of the risk of financial fraud using the financial fraud risk self-assessment tool described in the European Commission Guidelines,

(2) take into account the European Commission's Anti-Corruption Report when assessing the perceived level of exposure to corruption and financial fraud, and draw attention to the corruption perception index developed by Transparency International, as the perception level of corruption by business people and analysts from around the world, including national experts,

(3) introduce reliable control systems to reduce the likelihood of financial fraud risk materialising,

(4) introduce additional financial fraud detection procedures where necessary, and take appropriate action if their occurrence is suspected.

Full cooperation and coordination between the managing authority, the intermediary authority and other institutions involved in the implementation of the operational programmes and the investigative bodies and institutions involved in the fight against fraud are ensured in order to ensure an effective fraud preventing and combating policy.

\section{Ethical principles of employees behaviour in the process of EU funds management}

According to Regulation 1303/2013, each institution participating in the EU funds management process must set up appropriate procedures to prevent potential instances of financial fraud and corruption, to discourage such actions. Those regulations are in particular aimed at:

(1) defining actions that constitute cases of fraud and corruption and raising awareness in this area,

(2) encouraging the prevention of such activities,

(3) defining standards of conduct,

(4) promoting methods of detecting irregularities and facilitating their understanding,

(5) identifying methods of dealing with and investigating cases of fraud and corruption, and reporting them.

In each institution participating in the EU funds management process, procedures were developed which set out principles whose observance by members of the Civil Service Corps are regulated by law and other documents including, but not limited to, the Code of Civil Service Ethics, European Commission Guidelines, and the management and control system within the operational programmes implementation. The managing authorities - the authorities intermediating in the implementation of the cohesion policy - cannot tolerate illicit conduct, in particular, corruption, financial fraud, tender conspiracy, or conflict of interest, in activities or operations undertaken in connection with the implementation and performance of operational programmes. ${ }^{9}$

${ }^{9}$ In the 2014-2020 financial perspective, six National Operational Programmes and 16 Regional Operational Programmes have been implemented. 
The employees of authorities involved in the implementation and management of operational programmes should maintain the highest level of reliability and effectiveness in all their responsibilities. Their task is also to accurately and reliably control the management of funds and to report cases of illegal conduct to the competent investigating authorities. The procedures require that perpetrators be punished in accordance with applicable national laws and effective actions be taken to recover the misused EU funds.

The main guiding principles and target standards in the conduct of the personnel of authorities involved in the spending of EU funds should include:

(1) ethics - the personnel of authorities involved in the implementation and management of operational programmes must adhere to the highest norms of ethical conduct and integrity.

(2) increased transparency - appropriate information on the use of EU funds should, where possible, be available in a format that can be audited, compared and analysed for anti-fraud purposes, in accordance with the relevant provisions on the protection of personal data.

(3) ability to effectively conduct investigations - meaning that the anti-fraud authorities and bodies should have access to the necessary information, in cooperation with the authorities and organisations being audited, in accordance with the applicable provisions.

Ethics plays a special role in the process of financial fraud prevention. The Code of Ethics for Civil Service is the most important document regulating ethical requirements for officials of authorities participating in the EU funds management process. It contains rules on performing duties, methods of performing duties and constitutional duties. According to its provisions, officials of authorities conducting specific tasks within the framework of operational programmes are legally obliged to observe the principles of ethics of the civil service corps ${ }^{10}$, should act lawfully, treat their service recipients impartially, and work reliably and professionally. They should maintain loyalty towards the authority and their superiors, refuse to execute illegal orders, and notify superiors of such cases. They should treat all participants equally in administrative proceedings, away from any influence or pressure. They can neither demand nor receive any economic or personal benefits. The Code also stresses that a member of the civil service corps must take care of the development of his/her own competencies and expertise and good interpersonal relations, and must be friendly towards other people and respectful of the principles of good behaviour. It emphasises the importance of the tasks performed for the state and the ministerial role of the administration.

Order No. 70 of the Prime Minister on guidelines for compliance with civil service rules and on the ethics of the civil service corps ${ }^{11}$, sets general standards for performing civil servant functions by a civil servant. Those principles also apply to performing tasks by public officials in managing EU funds. This document contains a number of key provisions that are relevant to limiting the risk of conflict. The first chapter includes a list of civil service principles that all officers agree to respect, which they sign on taking

\footnotetext{
${ }^{10}$ The Law of 21 November 2008 on civil servants (i.e. Journal of Laws of 2016, items 1345, 1605).

${ }^{11}$ Order No. 70 of the Prime Minister on guidelines for compliance with civil service rules and on the ethics of the civil service corps, issued on the basis of Article 15 paragraph 10 of the Act of 21.11.2008 on the Civil Service (i.e. Journal of Laws of 2016, item 1345, as amended).
} 
up public duties. In general, most of those principles more or less directly protect officials and authorities from conflicts of interest. It is worth drawing special attention to the principles of legality, selflessness, openness and transparency, professionalism, the rational management of public funds, the openness and competitiveness of recruitment for public administration positions, and the desire to enhance citizens' confidence in the state, referred to in the Order. Whenever there is a conflict of interest and an official takes a decision not guided by the public weal, but by private, family or specific groups weal, he/she breaks those principles; therefore he/she is acting a self-interested manner, unreasonably and unprofessionally.

Consequently, his/her decisions threaten the idea of democratic governance and the rule of law and jeopardise the confidence of citizens. The order, in its conception, emphasises what is meant by respecting those principles in practice, for example, by prohibiting civil servants from accepting additional (non-obligatory) benefits in return for their work or undertaking additional employment (of course with some exceptions, e.g., when such employment does not reduce the work efficiency and is done with the consent of a superior).

In implementing the principle of openness and transparency, officials are required to provide information on the principles and results of their work and on the decisions taken thereby. The settlements are to be unambiguous, clearly and duly justified, and understandable to those concerned. They are important guidelines for limiting conflicts of interest.

The openness and transparency of the decision-making process constitute the best guarantee that those decisions are in the public interest, not for other, contradictory aspirations. Moreover, only then can the decisions be subjected to social control (and not merely internal or political control) and become truly accountable.

In accordance with the principle of professionalism, officials are required to know the principles of the civil service and ethics, and to apply them in practice, while agreeing to verify that knowledge. Breaching those principles is an element taken into account in disciplinary proceedings - in specific situations when officials fail to perform their duties properly or exceed their competencies. The Civil Service Law ${ }^{12}$ outlines six ethics principles for the civil service corps: decent behaviour, public service, loyalty, political neutrality, impartiality, and reliability. As with the list included in the first chapter of the Order, all those principles can be linked to the issue of preventing a conflict of interest. Two of them are crucial for us - the principle of political neutrality and the principle of impartiality. The first implies, e.g., the prohibition of manifesting one's own political views and undertaking actions to support specific initiatives of this nature, and ensuring the transparency of relationships with people performing public political functions. Observance of this principle protects officials from politicisation and conflicts of interest that may arise therefrom.

The most important principle is that of impartiality, which is described by the document referring directly to the concept of conflict of interest. It is worth emphasising that this principle not only means that officials cannot be involved in a conflict of interest - the mere admis-

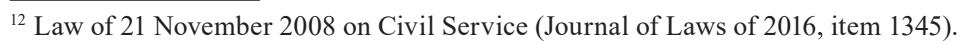


sion of the suspicion that, in performing their duties, they may have been involved in a conflict between private and public interests means that the principle has been broken.

The subsequent provisions of the order also mention typical situations where maintaining impartiality is impossible, e.g., undertaking tasks that interfere with official duties, yielding to pressure, or favouring certain participants in administrative matters. Interestingly, it is also important to maintain an adequate distance from people known publicly due to their political, economic, social or religious activities, rightly associating such behaviour with the risk of promoting not only specific views, but also groups usually represented by such individuals. Here, the risk of there being a conflict between public and private interests was noticed.

One of the key documents is the European Code of Good Administrative Behaviour, which was adopted by the European Parliament in 2001. The introduction of the Code has increased the quality of administration in EU institutions. The Code helps citizens to understand what administration standards they can expect from EU institutions. It also serves as a useful guide for civil servants in their dealings with the public. By making the principle of good administration more concrete, the Code promotes the highest standards of administration.

Ethical codes are an important element in the functioning of each office, as they directly affect the reduction of corruption, embezzlement and so-called bad practices. It reduces the number of situations in which nepotism, favouritism and conflicts of interest occur. It increases the trust of the petitioners, clients, contractors and partners. It also increases employee loyalty and the credibility of personnel. However, it should be emphasised that an official should be an ethical person, not only because of his/her commitment to adhere to the ethical code of the authority, but also because of the intrinsic, deep sense that he/she is representing an institution which is of fundamental importance to the community. Thus, an employee of an authority must perform his or her duties fairly and impartially, deal with the petitioners matters in accordance with the law and the prescribed procedure, take care of the timely, formal and substantive performance of the tasks, rationally manage the public funds, be courteous and kind, and care about honest client service. The existence of an anti-fraud culture is crucial both in halting potential fraudsters and in maximising personnel involvement in combating financial fraud within all authorities in the system of implementing operational programmes between 2014 and 2020. Such a culture can be built through the implementation of general mechanisms and behaviours:

(1) a declaration of purposes - a clear message visible to all internal and external observers that all the authorities aim to achieve the highest ethical norms in the implementation of individual operational programmes between 2014 and 2020.

(2) a signal from the top management - oral or written communications from the highest level of management of all institutions in the 2014-2020 operational programme implementation system, that personnel and beneficiaries are expected to apply the highest ethical standards of conduct,

(3) a code of conduct - a transparent code of ethics which all personnel of institutions belonging to the 2014-2020 operational programme implementation system must undertake to adhere to.

The most important principles and values that are to be followed by employees dealing with EU funds include: 
(1) the principle of purposefulness, i.e., the awareness of the overriding purpose of the work of the officials, which serves the public weal,

(2) the principle of professionalism, i.e., to perform one's own duties with the utmost care, using one's own knowledge and skills,

(3) the principle of acting in accordance with the applicable law, i.e. executing tasks based on the applicable law, with a view to the economical use of public funds;

(4) the principle of responsibility, i.e., employees undertaking responsibility for their actions and decisions,

(5) the principle of transparency, i.e., conducting activities transparently and allowing the beneficiary equal access to information,

(6) the principle of a friendly working environment, i.e., the authorities respect employees' rights and promote an equal employment opportunities policy,

(7) the principle of impartiality, i.e., equal treatment of all beneficiaries, compliance with conflicts of interest counteracting procedures, non-acceptance of beneficial or personal benefits from beneficiaries and the preservation of political neutrality,

(8) the principle of cooperation, i.e., employees guided by respect, kindness and understanding of society,

(9) the principle of striving for the development of the organisation, i.e., caring about the efficiency of systems and procedures, reducing bureaucracy, and effective communication.

In conclusion, employees of all authorities of the 2014-2020 operational programmes implementation system should strive to respect ethical principles and values. Compliance with ethics will reduce financial fraud in the management of EU funds.

Training and raising awareness of the personnel involved in the implementation of operational programmes co-financed by the EU has a significant impact on limiting the occurrence of financial fraud. As a consequence, the Operational Programme Managing Authorities conduct activities aimed at identifying, preventing and counteracting financial fraud, e.g., through the dissemination of documents and the organisation of meetings/ conferences, inter alia, for authorities/beneficiaries. In addition, the managing authority for the operational programme (MA) co-operates with the anti-fraud Working Group in cohesion policy funds set up on 7 November 2014 by the Chairman of the Interdepartmental Team for Combating Financial Irregularities.

Managing authorities also participate in the Anticorruption Team at the Ministry of Development within the framework of the Government Anti-Corruption Programme 2014-2019, coordinated by the Department of Control in the Ministry of Development.

All MA personnel of the operational programme implementation system in the financial perspective 2014-2020 were trained in theoretical and practical issues to raise awareness, promote anti-fraud culture, and facilitate the identification of, and response to, suspected financial fraud cases.

The training covered details of fraud prevention and combating policies, a description of roles and responsibilities, and reporting mechanisms. In particular, they concerned people who undertook work or performed tasks in threatened areas.

Raising the ethical awareness of employees dealing with EU funds should be systematic, e.g., by participating in conferences, on-line training, such as CBA websites, group work meetings, or in a less formal way, such as newsletters, posters and websites. 


\section{Types of irregularities, detection methods and the importance of the principles of ethics in the process of counteracting irregularities}

The subsequent multiannual frameworks of EU funds utilisation indicate that even the best-developed control procedures will not eliminate the risk of irregularities. This has been confirmed with the data published by the Ministry of Financeacting as the Payment Institutions with regard to the EU budget funds. The amount to which irregularities referred represented less than $2 \%$ of the total amount of the EU funds spent in Poland. The low rate of irregularities confirms the positive assessment of the applied system of EU funds control and management.

For the purpose of eliminating the risk of incorrect spending of the money originating from the structural funds and the Cohesion Fund, it may prove helpful to analyse the types of irregularities which reflect the legal regulations abused most often (Fig. 1).

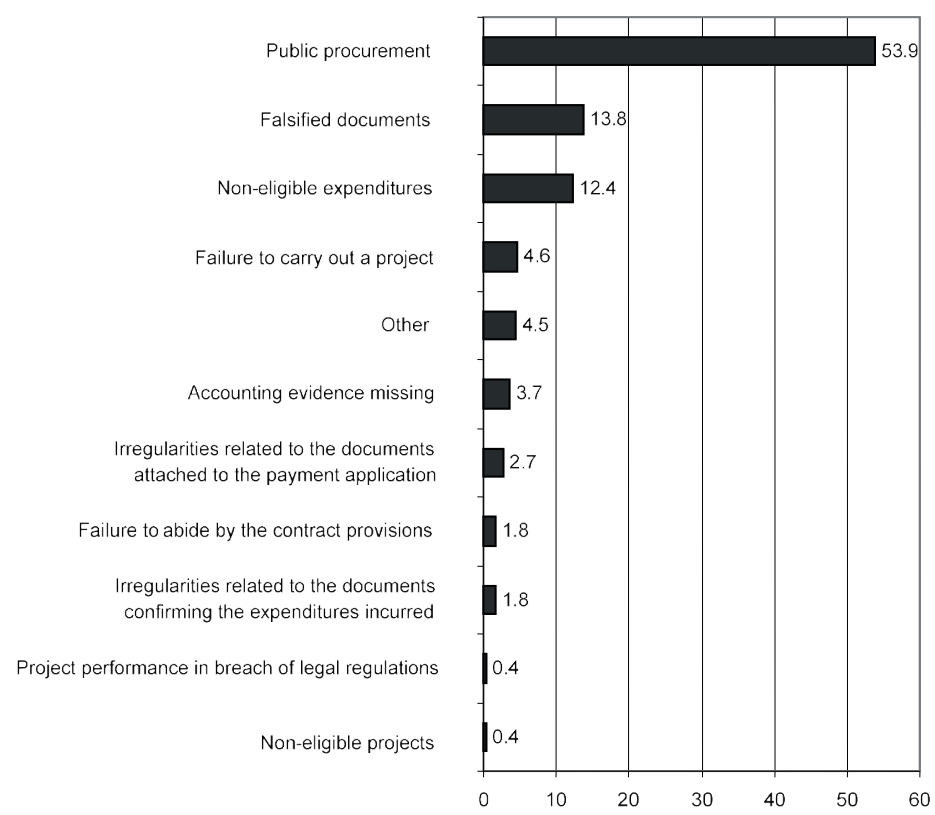

Fig. 1. Types of irregularities in spending EU funds reported to the European Commission (in \%)

Source: Ministry of Finance, Department of Certification and Acknowledgement of EU Funds (reports and papers by the Ministry of Finance, 2016).

The most effective method of detecting irregularities was control carried out ${ }^{13}$ by the institutions participating in the process of spending EU funds, i.e. verification of project subsidy applications and payment applications. Over $80 \%$ of improper spending of EU

\footnotetext{
${ }^{13}$ The questionnaire survey was carried out in 2016 in a group of 30 employees of the institutions participating in the implementation of the 2014-2020 Regional Operational Programme of the Podkarpackie Province (i.e. the Provincial Labour Office in Rzeszów and the following departments of the Office of the Governor of the
} 
funds was detected by the institutions involved in implementing the operational programmes, i.e. the Managing Authorities, Intermediate Bodies and Implementing Institutions. The state control system has very little effect in that regard.

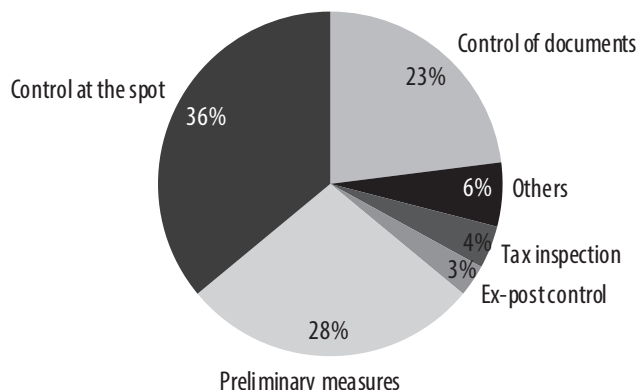

Fig. 2. Methods of detecting irregularities in the EU budget funds spending

Source: Ministry of Finance, Department of Certification and Acknowledgement of EU Funds (reports and papers by the Ministry of Finance, 2016).

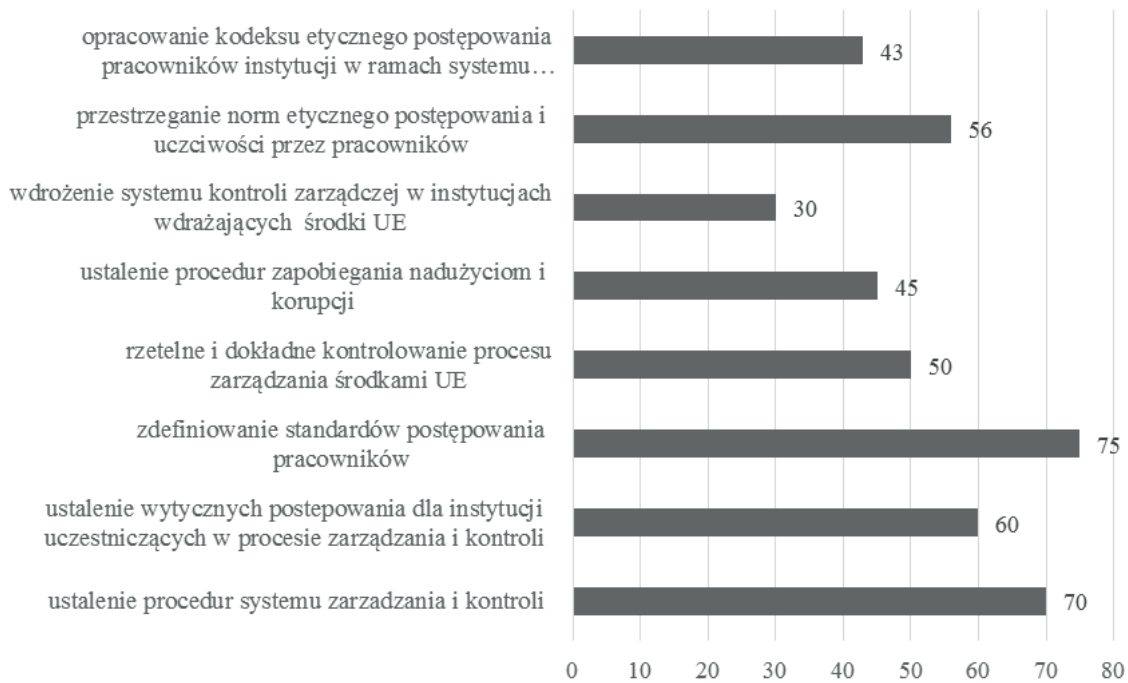

Fig. 3. Factors limiting the origination of irregularities ( $\%$ of responses)

Source: Proprietary materials developed based on the results of the questionnaire survey.

Podkarpackie Province: the Management of the Regional Operational Programme of the Podkarpackie Province, Regional Development, and Infrastructural Projects Implementation). 
The results of a questionnaire survey (Fig. 3) carried out among a select group of 30 employees of the institutions participating in the EU funds management reflected that in the process of limiting irregularities, a significant role was assigned to the principles of ethics in the conduct of the employees of institutions participating in the EU funds management. The most important limiting factor was the clear definition of employee conduct standards ( $75 \%$ of responses), and the determination of the procedures of the management and control system (70\% of responses). Employees abiding by the ethical conduct and honesty standards was mentioned by $56 \%$ of the respondents while $43 \%$ of them mentioned the development of the code of ethics for the employees of the institutions participating in the EU funds management process.

\section{Conclusions}

The European Commission has a comprehensive system of rules on ethics and integrity, applicable to employees and members of the Commission. ${ }^{14}$ Those rules were set for the 2014-2020 programming period. The European Commission provides for relevant training and refresher training for all new employees. The Commission guarantees that the ethical principles and values of the EU civil service shall be communicated top-down to all employees on a consistent and systematic basis and appropriate training will be provided. The Commission ensures the implementation of effective financial fraud prevention measures in its personnel recruitment and human resources policies. They should include effective control of the past of candidates for work in EU funds managing authorities. The applicable ethical principles established by the European Commission are included in the procedures for the implementation of individual operational programmes in Poland. Therefore, the norms and principles of the ethical conduct of civil servants involved in the management of EU funds were developed and implemented.

Analysis of the empirical material showed that in Poland an important role in the process of mitigating the misuse of EU funds under regional and central operational programmes was assigned to rules of ethics applicable to the conduct of employees of institutions involved in EU funds management. The clearly defined standards of employee conduct, as well as the determination of procedures of the management and control system, were the most important factors mitigating the irregularities. Another area was complying with the norms of ethical conduct and honesty by employees, and also the development of the code of ethical conduct of the employees of institutions participating in the EU funds management process.

\footnotetext{
${ }^{14}$ Code of conduct for commissioners (C (2011) 2904): http://ec.europa.eu/archives/commission_2010-2014/ pdf/code_conduct_en.pdf.
} 


\section{References}

Borowik G., Zwalczanie zmów cenowych jako zagrożenia ekonomicznych interesów RP - próba oceny skuteczności unormowań prawnych, „Przegląd Bezpieczeństwa Wewnętrznego” 2013, No. 9(5), pp. 167-193.

Dziadek K., Kontrola jako narzędzie wykrywania nieprawidłowości w wykorzystaniu funduszy unijnych, „Zeszyty Naukowe Uniwersytetu Szczecińskiego. Finanse. Rynki finansowe. Ubezpieczenia" 2011, No. 42, pp. 111-119.

Łacny J., Ochrona interesów finansowych Unii Europejskiej w dziedzinie polityki spójności, Wolters Kluwer, Warsaw 2010.

Office of Competition and Consumer Protection, Activity reports, "Tender Conspiracy” 2016.

\section{Legal acts}

Law of 21 November 2008 on civil servants (i.e. Journal of Laws of 2016, items 1345, 1605).

OJ 2004.90.864/30 - Treaty of European Union - consolidated text incorporating the amendment introduced by the Treaty of Lisbon.

Order No. 70 of the Prime Minister on guidelines for compliance with civil service rules and on the ethics of the civil service corps, issued on the basis of Article 15 paragraph 10 of the Act of 21.11.2008 on Civil Service (i.e. Journal of Laws of 2016, item 1345, as amended).

Regulation (EU) No. 1303/2013 of the European Parliament and of the Council of 17 December 2013 laying down common provisions on the European Regional Development Fund, the European Social Fund, the Cohesion Fund, the European Agricultural Fund for Rural Development and the European Maritime and Fisheries Fund and laying down general provisions on the European Regional Development Fund, the European Social Fund, the Cohesion Fund and the European Maritime and Fisheries Fund and repealing Council Regulation (EC) No. 1083/2006.

Regulation of the European Parliament and of the Council (EU, Euratom) No. 966/2012 of 25 October 2012, on the financial rules applicable to the general budget of the Union and repealing the Council Regulation (EU, Euratom) No. 1605/2002 (OJ No. UE L 298/4 of 26.10.2016). 
